\title{
EFFECTS OF PLANT GROWTH REGULATORS ON GROWTH AND YIELD OF PRE-BASIC SEED POTATO PRODUCTION UNDER GLASSHOUSE CONDITION
}

\author{
P. Bhattarai* \\ National Potato Research Program, Nepal Agricultural Research Council, Khumaltar, Nepal
}

\begin{abstract}
A glasshouse experiment was carried out to study the effect of Plant Growth Regulators (PGRs) on the production of pre-basic seed (PBS) potatoes, cv. Janakdev at Khumaltar, (1360 masl) Lalitpur, Nepal during autumn and spring seasons of 2014 and 2015 respectively. Four - week old virus free in vitro plantlets grown in tissue culture laboratory were planted with $20 \mathrm{~cm}$ distance between rows and $10 \mathrm{~cm}$ between plantlets under glasshouse in completely randomized design. Three growth regulators, paclobutrazol (50 ppm), daminozide (100 ppm), chlormequat chloride (Cycocel) (200 ppm) and simple water as control were used for single foliar spray 6 weeks after transplanting with four replications. Analysis showed that there were significant differences on growth parameters; plant survival, plant uniformity, plant height and yield components; number of minitubers per plant and per square meter in both the seasons. Significantly maximum number of potato minitubers was recorded in growth retardants treated plants as compared to control. Experimental results showed that maximum number of minituber $\left(22.9 /\right.$ plant and $\left.668.2 / \mathrm{m}^{2}\right)$ in autumn and $\left(23.7 /\right.$ plant and $\left.1185.0 / \mathrm{m}^{2}\right)$ in spring season were gained from paclobutrazole spray, which were statistically differed from those of other growth regulators and control. Plants without PGR and treated with daminozide produced the least amount of minituber per unit area. Plant height decreased in all growth regulators over control due to their inhibiting effect on growth of the plants. paclobutrazol significantly reduced plant height but produced larger and heavier minitubers compared to other treatments. Hence, the best PGR for optimum enhancement of minituber number and size was paclobutrazol. The results suggested that paclobutrazol could be used in pre-basic seed potato production, leading to maximum minituber production which ultimately gave higher returns. The study concluded that spraying growth retarding chemicals at grand growth stage checked the excessive vegetative growth and increased the number and size of minituber.
\end{abstract}

\footnotetext{
*Corresponding author email: prkash235@yahoo.com
} 
Keywords: Daminozide, chlormequat chloride, glasshouse, minituber, paclobutrazol, potato, plant growth regulators, pre-basic seed

\section{INTRODUCTION}

Potato (Solanum tuberosum L.) is one of the most important crops in Nepal. It is used as a major vegetables in terai and mid-hills and as a staple food in the high hills and mountains. According to recent statistics (ABPSD, 2015), it ranks fifth in area coverage (197,037 ha), second in quantity of production $(25,86,287$ tons) and first in productivity $\left(13.1 \mathrm{t} \mathrm{ha}^{-1}\right)$ compared with the main staple food crops of rice, maize, wheat and finger millet grown in Nepal. Despite its importance in food security and cash generation, the average productivity is very low which has been considered mainly due to unavailability of high quality seed potato tubers and several other factors.

Potato, being vegetatively propagated crop, is very prone to seed degeneration as several potato viruses accumulate to the seed tubers overtimes resulting in its reduced yield potential. So far, six major potato viruses, namely PLRV, PVS, PVX, PVY, PVA and PVM had been reported to infect potato crops in Nepal (Akius and Kloos, 1990; Ranjit et al., 1994). Seed potatoes should be replaced by high quality seed potatoes at regular intervals to overcome seed degeneration (Sakha and Rai, 2004). A continuous source of high quality seed potatoes is, therefore, necessary in the country.

Pre-basic seed (PBS) potatoes are disease free potato minitubers produced by transplanting pathogen free in vitro potato plantlets under protected condition in aphid-proof glasshouse and/or screen house. Since 1990, National Potato Research Program (NPRP) has been producing about 2,00,000 number of pre-basic seeds annually, out of which approximately $35 \%$ PBS were small sized $(<0.5 \mathrm{~g}$ size $)$, which are difficult for direct planting in the farmer's field condition (NPRP, 2016). Those farmers who are involved in potato seed production are always demanding for bigger size (>1 g size) of PBS.

PBS production practice is to increase productivity by replacing old degenerated seed potatoes from the major seed potato production pocket areas of the country. PBS production per plant is very low (1:5-6), so it needs to increase at least by 1:9-10. PBS demand was about 0.4 million in the year 2011 (NPDP, 2011) while it increased up to 1 million in 2015 (NPRP, 2015). Compared to the country demand of about 1 million, supply of about 0.2 million tuberlets is far below and private seed industries are also in their infant stage. Intervention of efficient technologies to increase productivity of PBS potato minituber under glass/screen house is an urgent need to fulfil this demand.

Recently minitubers productions become popular worldwide. In this system, in vitro plantlets are produced that can be used for further rapid multiplication (in vitro), 
micro tuber production (in vitro), minituber production (in the greenhouse) (Struik and Lommen, 1990). The size of minitubers is from 5-25 mm. and their weight range is from 0.1-10 g or even more (Struik, 2007). Minitubers have the least amount of pathogens (Balali et al., 2008). Minitubers production from in vitro plantlets allows a faster multiplication rate in seed tubers (Imma and Mingo-Castel, 2006).

One of the major constraints in the productivity of potato minituber is excessive growth of haulm at the cost of stolen formation, tuberization \& tuber bulking under glass house condition. There is also a major challenge to increase the size of potato minituber. These twin objectives could be achieved by spraying growth retarding chemicals at grand growth phase, thereby checking the excessive vegetative growth and enhancing more translocation of photosynthates to the tuber for increasing the number and size of tuber. There are many plant growth regulators (PGRs) especially plant growth retardants used for inhibiting excessive vegetative growth of plants including potato. These PGRs can also be used for long term conservation of potato germplasms under different conditions. The PGRs are used in potato production for changing different characters of the plant such as: numbers of tubers, secondary growth in field and length time of plantlet and microtuber production in vitro (Struik and Wiersema, 1999).

Some reports reported that Coumarin (EL-Sawy et al., 2007), Etephon (Mele et al., 1982) and Paclobutrazole (Davis et al., 1988) often showed inhibiting growth effect. With using other exogenous cytokinin, the number of tubers has been increased most of times (Ewing and Struik, 1992). One of these growth regulators is Thidiazuron that acts the same as cytokinins and has cytokinin like effects (Pavlista and Gall, 2010). The application of plant growth regulators for tuberization, is a componential process. Therefore, there are several methods that produce a balance in PGRs for inducing tuberization (Tovar et al., 1985).The main goal of this research is exploring the effects of plant growth regulators under glasshouse on the production of minituber and diverse effects of these PGRs on number and size of minitubers.

\section{MATERIALS AND METHODS}

The study was carried-out during 2013-14 to 2014-15 under glasshouse conditions at NPRP, Khumaltar, Lalitpur, Nepal.

\section{Plant materials}

For conducting the experiment, virus-free in vitro plantlets of cv. Janakdev were propagated in NPRP Laboratory by single node cuttings (SNCs) on MS medium and incubated for four weeks (Dhital and Lim, 2004). Thermotherapy cum meristem tip excision technique was used to eliminate potato viruses. Clones regenerated from meristem culture were utilized for virus testing by DAS-ELISA (Double Antibody Sandwitched Enzyme Linked Immunosorbant Assay) technology. Virus-free in vitro plantlets were rapidly propagated by single nodal cuttings on modified MS solid media supplemented with $2 \mathrm{mg} \mathrm{l}^{-1}$ calcium pantothenate. With subsequent 
subcultures, desired numbers of in vitro plantlets of required cultivar Janakdev were obtained for transplantation. The cultures were incubated in growth chambers with culture conditions of $16 \mathrm{~h}$ photo period, 2000 lux light intensity and $20 \pm 2{ }^{\circ} \mathrm{C}$ temperatures.

\section{Hardening}

Before using plantlet in glasshouse we did hardening of plantlets. This operation was necessary for optimum growth of plantlets in glasshouse. In general, four week old plantlets were acclimatized and planted in bench prepared under glasshouse.

\section{Planting in glasshouse for minituber production}

Four week old in vitro plantlets were transplanted into sterile mixture of 2:1 sand and soil substrate under aphid-proof glasshouse for pre-basic seed production. Special cultivation techniques such as planting by making 1.5 -2 inch deep hole in trench (furrow) @ spacing of $10 \mathrm{~cm}$ between two $20 \mathrm{~cm}$ spaced ridges, irrigation with UV sterilized water, fertilizer application, earthing up, plant protection and haulm pulling were used between transplantation and harvest. Chemical fertilizers were applied at the rate of 200:200:120 NPK kg ha- ${ }^{1}$. Maintained day temperatures of $<25{ }^{\circ} \mathrm{C}$ and relative humidity $>75 \%$ by applying sprinkle irrigation at 2 days interval and manually operated other cooling system were applied to reduce the temperature. Media contained two parts sand and one part soil dried faster so, plants need frequent irrigation under naturally ventilated glasshouse.

\section{Spraying plant growth regulators}

Three growth regulators, paclobutrazol $(50 \mathrm{ppm})$, daminozide $(100 \mathrm{ppm})$ and chlormequat chloride (Cycocel) $(200 \mathrm{ppm})$ were used for single foliar spray and control i.e., water spray. PGRs used in experiment were from Flukar SIGMAALORICH Company. The spraying of PGRs was done 6 weeks after planting.

\section{Minituber harvesting}

Irrigation was stopped at least two weeks before harvest and haulms pulled a week ahead of harvesting. After 110 days, minituber were harvested and kept in shade in room temperature for a week. After that the number, size and weight of minituber per plot was recorded to assess the direct effects of PGRs on tuberization.

\section{Data recording}

During growth period, the plant growth traits such as plant survival, plant uniformity (1-5 scale), ground coverage (\%), number of stems plant ${ }^{-1}$ (no.) and plant height $(\mathrm{cm})$ were observed. After harvesting, minitubers were graded as NPRP system (>5 g, 1-5 g, 0.5-1 g. 0.25-0.5 g and <0.25 g). Minituber number plant ${ }^{-1}$, plot $^{-}$ ${ }^{1}, \mathrm{~m}^{2-1}$ and average size of minituber were recorded. 


\section{Experimental design and statistical analysis}

The experiment was carried out in a completely randomized design (CRD) with four replications. Four treatments included three PGRs and one control i.e., water spray. The individual plot size was $2 \mathrm{~m} \times 1.4 \mathrm{~m}$ with ten rows and 140 in-vitro plantlets. The data were statistically analyzed using computer software package MSTAT-C, version 1.3 and DMRT of MSTATC was also used for mean comparison.

\section{RESULTS}

\section{Autumn Season}

Results showed that maximum plant survival was gained from paclobutrazol and Cycocel $(100 \%)$ which were statistically different from two other treatments. Maximum plant uniformity (5) and number of stems per plant (7.3) were recorded form spraying paclobutrazol as compared to other treatments. It was observed that all the growth parameters studied except ground coverage was statistically significant with respect to applied treatments (Table 1). There was a significant reduction in plant height due to application of PGRs (growth retardants), where maximum plant height $(68.4 \mathrm{~cm})$ was observed in control (no PGRs spray) and minimum was in paclobutrazol $(30.5 \mathrm{~cm})$. Generally, Cycocel (200 ppm) and daminozide (100ppm) registered higher values of plant height as compared to paclobutrazol indicating that superiority of these chemicals in bringing about enhanced growth (Table 1).

Table 1. Effects of PGR on plant survival and growth parameters of PBS potato production under glasshouse condition during autumn season at Khumaltar, Lalitpur, 2014

\begin{tabular}{l|c|c|c|c|c}
\hline Treatments & $\begin{array}{c}\text { Plant } \\
\text { survival } \\
(\%)\end{array}$ & $\begin{array}{c}\text { Plant } \\
\text { uniformity } \\
(1-5)\end{array}$ & $\begin{array}{c}\text { Ground } \\
\text { Cover } \\
(\%)\end{array}$ & $\begin{array}{c}\text { Stems } \\
\text { plant } \\
(\mathrm{No})\end{array}$ & $\begin{array}{c}\text { Plant } \\
\text { height } \\
(\mathrm{cm})\end{array}$ \\
\hline Paclobutrazol @50 ppm & $100.0 \mathrm{a}$ & $5.0 \mathrm{a}$ & 95.0 & $7.3 \mathrm{a}$ & $30.5 \mathrm{~b}$ \\
Daminozide @ 100 ppm & $95.0 \mathrm{~b}$ & $4.0 \mathrm{bc}$ & 90.0 & $5.9 \mathrm{ab}$ & $60.7 \mathrm{a}$ \\
Chlormequat chloride @200 & $100.0 \mathrm{a}$ & $3.0 \mathrm{c}$ & 90.0 & $4.3 \mathrm{~b}$ & $58.0 \mathrm{a}$ \\
ppm & & & & & \\
Control(no PGRs spray) & $96.0 \mathrm{~b}$ & $4.0 \mathrm{ab}$ & 90.0 & $4.7 \mathrm{~b}$ & $68.4 \mathrm{a}$ \\
P value & 0.0250 & 0.0014 & 0.0728 & 0.0264 & 0.0002 \\
Significance & $*$ & $* *$ & $\mathrm{NS}$ & $*$ & $* * *$ \\
CV(\%) & 2.38 & 9.61 & 15.22 & 23.36 & 15.22 \\
\hline
\end{tabular}

$\mathrm{NS}=$ not significantly different, *significant at $<0.05$, **highly significant at $<0.01$ and $* * *$ highly significant at $<0.001$ levels, respectively.

In column figures with similar small letter(s) do not differ significantly by DMRT at 0.05 level, Plant uniformity: $1=$ very poor, $2=$ poor,

3 =fair, 4=good and 5=excellent 
The effect of PGRs on minituber plant ${ }^{-1}$ was highly significant $(\mathrm{P}<0.001)$. Plants sprayed with paclobutrazol produced significantly more number of PBS (22.9) plant $^{-1}$ compared with the other two PGRs (Figure 1). The least minituber number plant $^{-1}$ (14.5) was produced with control treatment, while daminozide and Cycocel slightly increased the number of minituber however, differences was at par statistically (Table 2).

The effect of PGRs on minituber size ( $>5 \mathrm{~g})$ and $(0.5-1 \mathrm{~g})$ was highly significant $(\mathrm{P}<0.001)$ and $(\mathrm{P}<0.01)$ respectively. Paclobutrazol produced maximum number (208.0) of the largest minituber plot $^{-1}$ followed by Cycocel (201.8). PGRs had no significant effect on the production of PBS size (1-5 g, 0.25-0.5 g and $<0.25 \mathrm{~g}$ ). Results showed that, maximum number of minituber $\left(668.2 \mathrm{~m}^{2-1}\right)$ produced with the application of Paclobutrazol while minimum number $\left(469.3 \mathrm{~m}^{2-1}\right)$ was recorded from control treatment (Table 2).

Table 2. Effects of PGR on yield characters of PBS potato production under glasshouse condition during autumn season at Khumaltar, Lalitpur, 2014

\begin{tabular}{|c|c|c|c|c|c|c|c|c|}
\hline \multirow[t]{2}{*}{ Treatments } & \multirow{2}{*}{$\begin{array}{l}\text { Minituber } \\
\text { plant }^{-1} \\
(\mathrm{No})\end{array}$} & \multicolumn{5}{|c|}{ PBS size distribution by weight $(\mathrm{g}) \&(\mathrm{No})$} & \multirow{2}{*}{$\begin{array}{c}\text { Total } \\
\text { Minituber } \\
\text { Plot }^{-1}(\mathrm{No})\end{array}$} & \multirow{2}{*}{$\begin{array}{c}\text { Minituber } \\
\mathrm{m}^{2-1} \\
(\mathrm{No})\end{array}$} \\
\hline & & $>5 \mathrm{~g}$ & $1-5 \mathrm{~g}$ & $0.5-1 \mathrm{~g}$ & $0.25-0.5 \mathrm{~g}$ & $<0.25 \mathrm{~g}$ & & \\
\hline Paclobutrazol@50ppm & $22.9 \mathrm{a}$ & $208.0 \mathrm{a}$ & 794.0 & $616.0 \mathrm{a}$ & 173.5 & 79.5 & $1871.0 \mathrm{a}$ & $668.2 \mathrm{a}$ \\
\hline Daminozide@100 & $16.3 \mathrm{~b}$ & $95.5 \mathrm{~b}$ & 629.3 & $555.5 \mathrm{a}$ & 187.0 & 79.8 & $1547.0 \mathrm{ab}$ & $552.5 \mathrm{ab}$ \\
\hline $\begin{array}{l}\text { Chlormequat } \\
\text { chloride@200ppm }\end{array}$ & $16.6 \mathrm{~b}$ & $201.8 \mathrm{a}$ & 583.3 & $510.3 \mathrm{a}$ & 185.5 & 93.3 & $1574.0 \mathrm{ab}$ & $562.1 \mathrm{ab}$ \\
\hline $\begin{array}{l}\text { Control(no PGRs } \\
\text { spray) }\end{array}$ & $14.5 \mathrm{c}$ & $170.8 \mathrm{a}$ & 687.0 & $293.3 \mathrm{~b}$ & 108.8 & 54.3 & $1314.0 \mathrm{~b}$ & $469.3 \mathrm{~b}$ \\
\hline$P$ value & 0.0000 & 0.0001 & 0.1053 & 0.0044 & 0.1526 & 0.4143 & 0.0332 & 0.0332 \\
\hline Significance & $* * *$ & $* * *$ & NS & $* *$ & NS & NS & $*$ & $*$ \\
\hline $\mathrm{CV}(\%)$ & 5.79 & 14.31 & 16.93 & 20.821 & 31.24 & 41.85 & 14.39 & 14.39 \\
\hline
\end{tabular}

$\mathrm{NS}=$ not significantly different, *significant at $<0.05$, **highly significant at $<0.01$ and $* * *$ highly significant at $<0.001$ levels, respectively.

In column figures with similar small letter(s) do not differ significantly by DMRT at 0.05 level.

\section{Spring Season}

Plant survival of potato plants was not significantly affected with the application of PGRs. Other growth parameters like plant uniformity, ground coverage and plant height had the significant response of PGRs (Table 3). The number of stems per plant had no significant effect of PGRs. The data indicated that there was significant decrease in the plant height of potato plants which were subjected to the foliar application of PGRs compared with control where only water was sprayed and same trend was found in case of autumn season. The lowest plant height $(22.6 \mathrm{~cm})$ was observed in the application of paclobutrazol as compared to other two PGRs and the highest plant height $(69.3 \mathrm{~cm})$ was recorded with water spray (control). 
Table 3. Effects of PGR on plant survival and growth parameters of PBS potato production under glasshouse condition during spring season at Khumaltar, Lalitpur, 2015

\begin{tabular}{l|c|c|c|c|c}
\hline \multicolumn{1}{c|}{ Treatments } & $\begin{array}{c}\text { Plant } \\
\text { survival (\%) }\end{array}$ & $\begin{array}{c}\text { Plant } \\
\text { uniformity } \\
(1-5)\end{array}$ & $\begin{array}{c}\text { Ground } \\
\text { Cover }(\%)\end{array}$ & $\begin{array}{c}\text { Stems } \\
\text { Plant } \\
(\mathrm{No})\end{array}$ & $\begin{array}{c}\text { Plant } \\
\text { height }(\mathrm{cm})\end{array}$ \\
\hline Paclobutrazol @ 50 ppm & 98.8 & $5.0 \mathrm{a}$ & $95.0 \mathrm{c}$ & 5.4 & $22.6 \mathrm{c}$ \\
Daminozide @ 100 ppm & 97.5 & $4.0 \mathrm{~b}$ & $97.5 \mathrm{~b}$ & 5.4 & $39.8 \mathrm{~b}$ \\
Chlormequat chloride & 97.5 & $4.5 \mathrm{ab}$ & $100.0 \mathrm{a}$ & 4.7 & $44.9 \mathrm{~b}$ \\
@200 ppm & 97.5 & $4.5 \mathrm{ab}$ & $100.0 \mathrm{a}$ & 4.3 & $69.3 \mathrm{a}$ \\
Control(no PGRs spray) & - & 0.0346 & 0.0009 & 0.2225 & 0.0000 \\
P value & $\mathrm{NS}$ & $*$ & $* *$ & $\mathrm{NS}$ & $* * *$ \\
Significance & 3.54 & 9.07 & 1.47 & 16.57 & 17.70 \\
CV(\%) & & &
\end{tabular}

$\mathrm{NS}=$ not significantly different, * significant at $<0.05$, **highly significant at $<0.01$ and $* * *$ highly significant at $<0.001$ levels, respectively.

In column figures with similar small letter(s) do not differ significantly by DMRT at 0.05 level, Plant uniformity: $1=$ very poor, $2=$ poor,

$3=$ fair, $4=$ good and $5=$ excellent

Table 4. Effects of PGR on yield characters of PBS potato production under glasshouse condition during spring season at Khumaltar, Lalitpur, 2015

\begin{tabular}{|c|c|c|c|c|c|c|c|c|}
\hline \multirow[t]{2}{*}{ Treatments } & \multirow{2}{*}{$\begin{array}{c}\text { Minituber } \\
\text { plant }^{-1} \\
(\mathrm{No})\end{array}$} & \multicolumn{5}{|c|}{ PBS size distribution by weight( $\mathrm{g}) \&(\mathrm{No})$} & \multirow{2}{*}{$\begin{array}{c}\text { Total } \\
\text { Minituber } \\
\text { Plot }^{-1} \\
(\mathrm{No}) \\
\end{array}$} & \multirow{2}{*}{$\begin{array}{c}\text { Minituber } \\
\mathrm{m}^{2-1} \\
\text { (No) }\end{array}$} \\
\hline & & $>5 \mathrm{~g}$ & $1-5 \mathrm{~g}$ & $0.5-1 \mathrm{~g}$ & $0.25-0.5 \mathrm{~g}$ & $<0.25 \mathrm{~g}$ & & \\
\hline $\begin{array}{l}\text { Paclobutrazol } \\
@ 50 \text { ppm }\end{array}$ & $23.7 \mathrm{a}$ & $32.3 \mathrm{a}$ & $417.3 \mathrm{a}$ & 1203.5 & 832.5 & $832.5 \mathrm{~b}$ & $3318.0 \mathrm{a}$ & $1185.0 \mathrm{a}$ \\
\hline $\begin{array}{l}\text { Daminozide } \\
@ 100 \text { ppm }\end{array}$ & $20.9 \mathrm{a}$ & $15.0 \mathrm{~b}$ & $281.0 \mathrm{~b}$ & 1044.0 & 621.0 & $960.0 \mathrm{ab}$ & $2921.0 \mathrm{a}$ & $1043.2 \mathrm{a}$ \\
\hline $\begin{array}{l}\text { Chlormequat } \\
\text { chloride } \\
\text { @200ppm }\end{array}$ & $22.2 \mathrm{a}$ & $12.0 \mathrm{~b}$ & $379.5 \mathrm{a}$ & 1057.5 & 540.0 & $1122.5 \mathrm{a}$ & $3111.5 \mathrm{a}$ & $1111.3 \mathrm{a}$ \\
\hline $\begin{array}{l}\text { Control(no PGRs } \\
\text { spray) }\end{array}$ & $11.5 \mathrm{~b}$ & $1.5 \mathrm{c}$ & $167.0 \mathrm{c}$ & 676.0 & 367.0 & $400.0 \mathrm{c}$ & $1611.5 \mathrm{~b}$ & $575.5 \mathrm{~b}$ \\
\hline$P$ value & 0.0105 & 0.000 & 0.0000 & 0.0804 & 0.1076 & 0.0002 & 0.0105 & 0.0105 \\
\hline Significance & $*$ & $* * *$ & $* * *$ & NS & NS & $* * *$ & $*$ & $*$ \\
\hline $\mathrm{CV}(\%)$ & 23.19 & 27.66 & 11.25 & 26.64 & 41.28 & 19.17 & 23.18 & 23.18 \\
\hline
\end{tabular}

$\mathrm{NS}=$ not significantly different, *significant at $<0.05, * *$ highly significant at $<0.01$ and $* * *$ highly significant at $<0.001$ levels, respectively.

In column figures with similar small letter(s) do not differ significantly by DMRT at 0.05 level 


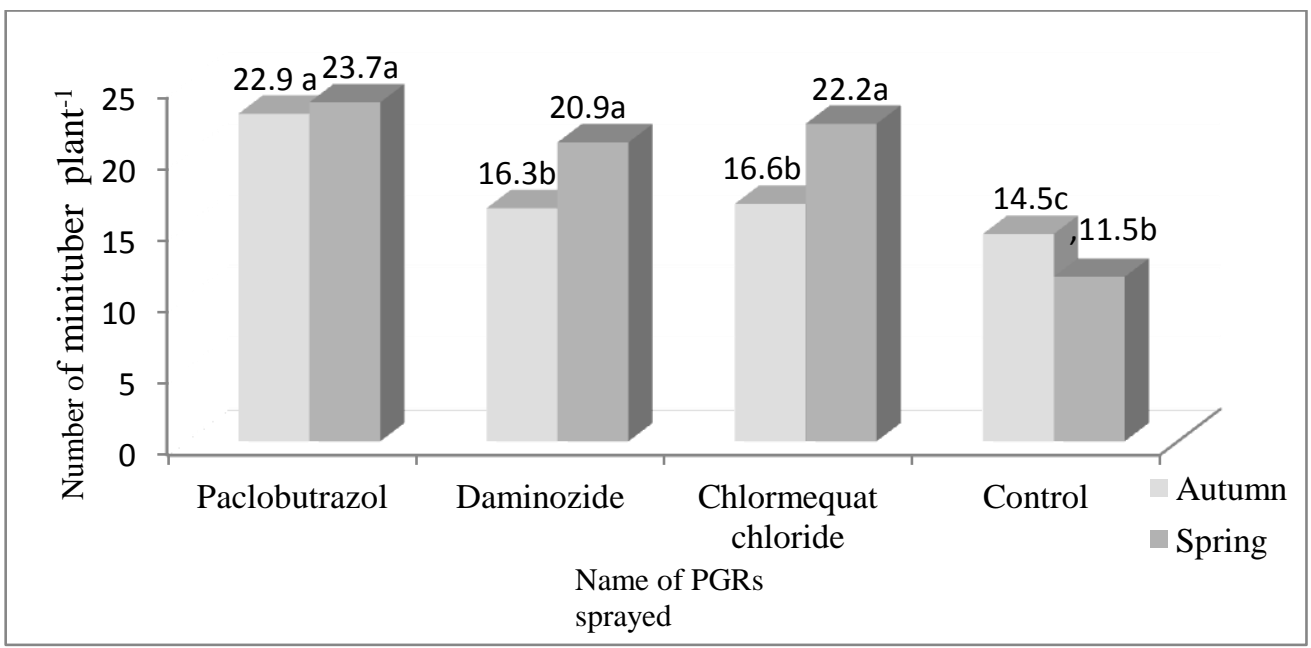

Figure 1. The comparison of the PGRs on production of minituber number plant ${ }^{-1}$ during autumn and spring season

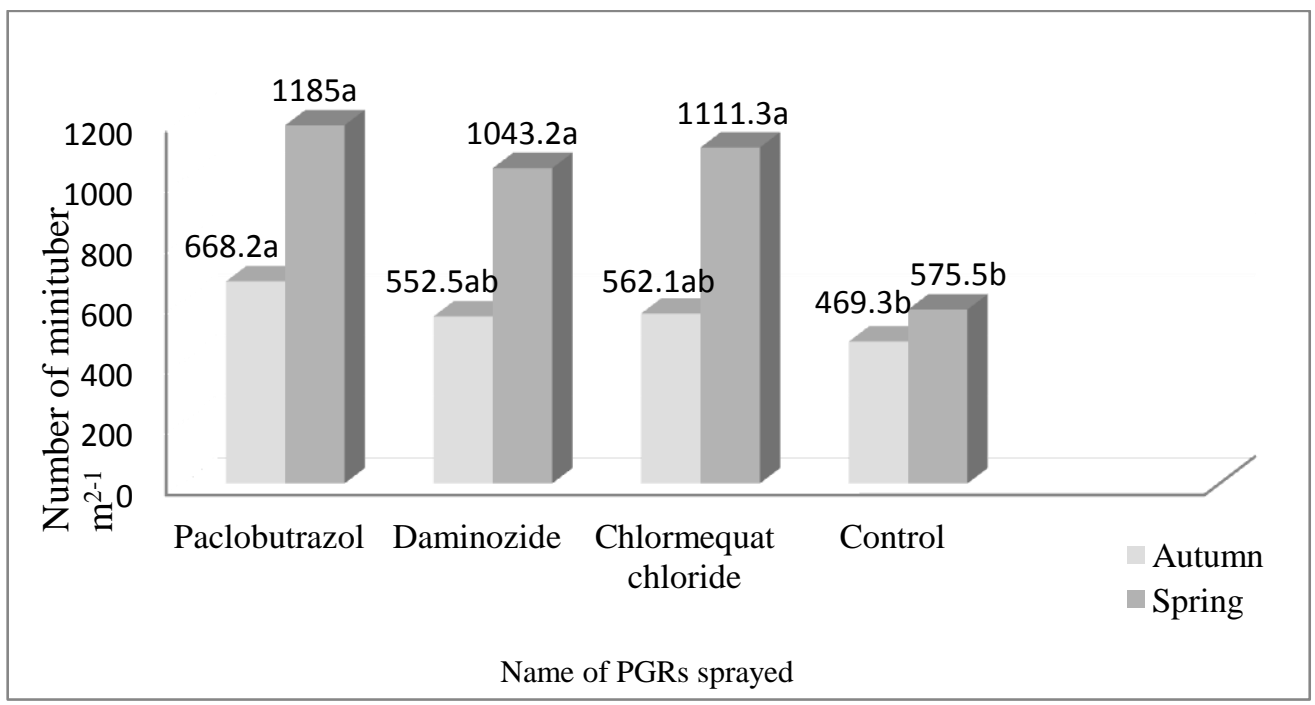

Figure 2. The comparison of the PGRs on production of minituber number $\mathrm{m}^{2-1}$ during autumn and spring season

The spraying of PGRs gave significantly higher number of minituber plant $^{-1}$ than control treatment (Table 4). Among the various PGRs, the number of minituber was maximum (23.7) with paclobutrazol followed by Cycocel (22.2) as compared to control (11.5) (Figure 1). Minituber size was also affected by the application of 
PGRs. The results revealed that PBS size ( $>5 \mathrm{~g}, 1-5 \mathrm{~g}$ and $<0.25 \mathrm{~g}$ ) was highly significant $(\mathrm{P}<0.001)$ due to the applications of PGRs. Maximum number of large size minituber was produced by the application of paclobutrazol which were 32.3 $\operatorname{plot}^{-1}(>5 \mathrm{~g})$ and $417.3 \mathrm{plot}^{-1}(1-5 \mathrm{~g})$. The results showed that control treatment reduced the number of big size minituber. Total number of minituber $\mathrm{m}^{2-1}$ was the highest in paclobutrazol (1185.0) which were statistically differed from control (575.5) and at par with Cycocel (1111.3) and daminozide (1043.2) (Table 4).

\section{DISCUSSION}

It is evident from the data presented in the preceding chapter that PGRs had significant effect on vegetative growth parameters like plant uniformity, number of stems plant ${ }^{-1}$ and plant height during autumn season while percentage of ground coverage was not significantly differed among the studied treatments (Table 1). Plant survival also differed with each other. In case of spring season, plant survival and number of stems plant ${ }^{-1}$ was not significantly affected by the application of PGRs, but growth parameters plant height, plant uniformity and ground coverage were significantly influenced (Table 3). Trend of low ground coverage percentage was noticed in the plants subjected to the foliar application of growth retardants as compared to control treatment indicating that application of PGRs reduced leaf area of potato plant. Though, there was an increase in the number of stems plant ${ }^{-1}$, but there was decrease in ground coverage due to the application of growth retardants, which could be mainly attributed not only to decrease in the plant height but due to decreased cell division and cell expansion. The present findings are also consistent with the results of Prakash et al. (2001) in potato. Studies indicated that leaf area was reduced due to the application of growth retardants (Govindakrishna and Sahota, 1984; Madalageri, 1996).

The data indicated that there was a significant decrease in plant height due to the application of growth retardants (Table $1 \& 3$ ). The height declined due to inhibiting effect of PGRs. There was the highest number of stems per plant but low plant height with the application of paclobutrazol which might be due to growth retarding properties which increased the minituber number rather than maximum vegetative growth of the plants (Table 3). Results showed that paclobutrazol was more effective to reduce the plant height as compared to other two growth retardants. Similar results were reported by Bandara and Tanino (1995) in potato. The inhibitory effect of paclobutrazol on vegetative growth in potatoes was also reported by Simco (1991) in vitro and by Balamani and Poovaiah (1985) under greenhouse condition. Daminozide was used by the most bedding plant producers for height control of vegetable transplants for many years (Cantliffe, 2009).

The results (Table $2 \& 4$ ) revealed that there was a significant difference in number of minituber production plant ${ }^{-1}$ with the application of PGRs. The spraying of PGRs increased minituber number plant $^{-1}$ and $\mathrm{m}^{2-1}$. Among the various PGRs used, 
paclobutrazol gave the highest minituber number as compared to other two PGRs while, control treatment produced minimum minituber number (Figure 1\&2). Treatment with paclobutrazol promoted tuberization in potatoes under in vitro (Harvey et al., 1991; Simco, 1991) and under greenhouse conditions (Balamani and Poovaiah, 1985; Bandara and Tanino, 1995). Banerjee and Das (1984) also reported an increased tuber yield and yield components due to the application of growth retardants. PBS size was also significantly influenced by the application of PGRs. Paclobutrazol produced the maximum number of heavier and larger minituber than other PGRs (Table 2\&4). The results of the present investigation are in agreement with the results of Kianmehr et al. (2012) and Bandara et al. (1998). Paclobutrazol is a triazole compound which inhibits extension growth in many plant species and blocks GA biosynthesis in plants (Davis et al., 1988). It has also been shown to inhibit shoot growth in a wide range of plant species (Barrett and Bartuska, 1982; Child et al., 1993) including potatoes (Balamani and Poovaiah, 1985; Pelacho et al., 1994).

\section{CONCLUSION}

From the study, it is concluded that spraying growth retardants gave significantly higher number and larger size of potato minituber than control. Hence, the best PGR for optimum enhancement of minituber number and size was paclobutrazol with implication for quality seed potato. The results suggest that paclobutrazol @50 ppm could be used in pre-basic seed potato production, leading to maximum minituber production under glasshouse.

\section{REFERENCES}

ABPSD, 2015. Statistical Information on Nepalese Agriculture. Agri-business, Promotion and Statistics Division, Ministry of Agricultural Development, Singhadarbar, Kathmandu. p. 14

Akius, M. and Kloos, J.P. 1990. Viral disease spread and detection in Nepal. Proceeding of $11^{\text {th }}$ European Association for potato Research (EAPR), Edinburgh. pp. 66-67

Anonymous, 2011. Impact assessment on Pre-basic seed (PBS) of Potato in Nepal. National Potato Development Programme, Department of Agriculture, Khumaltar, Lalitpur, Nepal. pp. 1-4

Anonymous, 2015. Annual Report. National Potato Research Programme, Nepal Agricultural Research Council, Khumaltar, Lalitpur. pp. 81-82

Anonymous, 2016. Annual Report. National Potato Research Programme, Nepal Agricultural Research Council, Khumaltar, Lalitpur. pp. 82-83

Badara, P.M.S. and Tanino, K.K.1995. Paclobutrazol enhances minituber production in Norlands potatoes. Journal of Plant Growth Regulation, 14: 151-155

Balali, G.R., Hadi, M.R., Yavari, P., Bidram, H., Naderi, A.G. and Eslami, A. 2008. Effect of pot size, planting date and genotype on minituber production of Marfona potato cultivar. African Journal of Biotechnology, 7: 1265-1270 
Balamani, V. and Poovaiah, B.W. 1985. Retardation of shoot growth and promotion of tuber growth of potato plants by paclobutrazol. American Potato Journal, 62:363-369

Bandara, M.S., Tanino, K.K. and Waterer, D.R. 1998. Effect of Pot Size and Timimng of Plant Growth Regulator treatments on Growth and Tuber Yield in Greenhouse-Grown Norland and Russet Burbank Potatoes. Journal of Plant Growth Regulation, 17:75-79

Banerjee, N.C. and Das, T.K. 1984. Effect of plant growth regulators on growth and tuber yield of potato. South Indian Horticulture, 32(2):75-77

Barrett, J.E. and Bartuska, C.A. 1982. PP 333 effects on stem elongation dependent on site of application. Horticultural Science, 17:737-738

Cantliffe, D.J. 2009. Plug Trasplant Technology. In: J. Janick. John Wiley and Sons (Eds). Horticultural Reviews, 35: 397-417

Child, R.D., Evans, D.E., Allen, J. and Arnold, G. M. 1993. Growth response in oilseed rape (Brassica napus L.) to combined applications of the triazole chemicals triapenthenol and tebuconazole and interactions with gibberellin. Plant Growth Regulation, 13:203212

Davis, T.D., Sankhla, N. and Upadhyaya, A.1988.Triazole plant growth regulators. Horticultural Reviews, 10: 63-105

Dhital, S.P. and Lim, H.T. 2004. Microtuberization response in several potato genotypes of potato by direct addition of liquid medium to in vitro plantlets. Journal of Korean Society of Horticultural Science, 45(6): 281-286

EL-Sawy, A. Bekheet, S. and Ibrahimaly, U.2007.Morphological and Molecular Characterization of Potato Microtubers Production on Coumarin Inducing Medium. International journal of agriculture and biology, 9(5):675-680

Ewing, E.E. and Struik, P.C. 1992. Tuber formation in potato: Induction, initiation and growth. Horticultural Reviews, 14: 89-198

Harvey, B.M.R., Crothers, S.H., Evens, N.E. and Selby, C. 1991. The use of growth retardants to improve microtuber formation by potato (Solanum tuberosum). Plant Cell Tissue Organ Culture, 27:59-64

Imma, F. and Mingo-Castel, A.M. 2006. Potato Mini-tuber Production Using Aeroponics: Effect of Plant Density and Harvesting Intervals. American Journal of Potato Research, 83: 47-53

Kianmehr, B., Otroshy, M., Parsa, M., Mohallati, M.N. and Moradi, K. 2012. Effect of Plant Growth Regulation during in vitro Phase on Potato Minituber Production. International Journal of Agriculture and Crop Sciences, 15(4):1060-1067

Mele, E., Messeguer, J. and Camprubi, P. 1982. Effect of ethylene on carnation explants grown in sealed vessels. (pp. 69-70), in Fujiwara (eds.) 1982(q.v.)

Pavlista, A. D. and Gall, C. 2010. Delaying Early Blight Onset in Potato with Thidiazuron. American Journal of Potato Research Tdz, 9-210

Pelacho, A.M., Martin-Closas, L., Campabadal, C., Torres, A. and Farran IMingo-Castel, A.M. 1994. In vitro tuberization of potato: Effect of several morphogenic regulators in light and darkness. Journal of Plant Physiology, 144:705-709 
Prakash, P., Chetti, M.B. and Patil, S.S. 2001. Effect of Plant Growth Regulators on Growth Parameters and Yield in Potato. Karnataka Journal of Agricultural Science, 14 (4):938-942

Ranjit, M., Rai, G.P., Manandghar, A. and Pandey, V. 1994. Virus testing and elimination of viruses from some local cultivars of potato (Solanum tuberosum) in Nepal. Proceeding of $4^{\text {th }}$ Asian potato Association (APA) Triennial Conference, 5-7 July, 1994 (ET Rasco, FB Aromin and CH Balaltro, eds). Dackwonryeong. pp. 95-99

Sakha, B.M. and Rai, G.P. 2004. Performance of in vitro plantlets and stem cuttings for prebasic seed potato production under glasshouse condition in Nepal. Proceeding of 4th National Horticulture Research Workshop, 2-4 Mar., 2004. NARC, Khumaltar, Lalitpur. pp. 186-189

Simco, I. 1991. In vitro potato tuberization afterb the treatment with paclobutrazol. Biologia, 46:251-256

Struik, P.C. 2007. The canon of potato science: Minitubers. Potato Research, 50:305-308

Struik, P.C. and Wiersema, S.G.1999.Seed Potato Technology. Wageningen Pers Wageningen The Netherlands, p. 383

Struik, P.C. and Lommen, W.M.J. 1990. Production, storage and use of micro- and minitubers. Proceeding of $11^{\text {th }}$ Triennial Conference of the European Association for potato Research (EAPR), Edinburgh. pp. 122-123

Tovar, P., Estrada, R., Schilde-Rentschler, L. and Dodds, J.H. 1985. Induction and use of in vitro potato tubers, CIP circular, 13:1-5. 